\title{
Mestrado profissional em terapia ocupacional na Universidade de São Paulo: apostando na força dos processos coletivos
}

[...] isso de querer ser exatamente aquilo que a gente é ainda vai nos levar além (LEMINSKI, 1987, p. 93).

Terminava o ano de 2018 quando nós, docentes de terapia ocupacional da Faculdade de Medicina da USP (FMUSP), recebemos a notícia que não deixava dúvidas se o ano que chegava seria realmente novo: nosso programa de pós-graduação Terapia Ocupacional e Processos de Inclusão Social havia sido aprovado pela CAPES.

Claro que essa aprovação revela o mérito da proposta e, considerando as dificuldades e desafios históricos que a terapia ocupacional brasileira tem enfrentado para se consolidar como área de produçáo de conhecimentos (EMMEL, 2017; GUEDES; LOPES, 2018), estamos convictos que a implantação de mais um programa de formação em nível de pós-graduaçáo stricto sensu é um passo muito importante.

Mas essa conquista tem, além dessas qualidades, um componente fundamental. Trata-se do fato da proposta se definir, acima de tudo, pela afirmação de alguns valores que, por vezes, pensamos não ser mais possível encontrar no mundo acadêmico: o respeito às diferenças e à ação coletiva. Em torno de uma vontade comum, projetamos, elaboramos e confrontamos ideias, fazendo desse um processo no qual pudemos nos ouvir e nos reinventar. E, nesse sentido, entre os anos de 2013 e 2018 construímos longo percurso, na USP e na CAPES, de resistência ao individualismo e à competitividade, que interrompem fluxos potentes de genuína curiosidade e produção de conhecimentos.

Assim, alguns docentes de terapia ocupacional da FMUSP, da Faculdade de Medicina de Ribeirão Preto e do Instituto de Psicologia da USP puderam reunir suas experiências, consolidadas em diferentes programas de pós-graduação, na criaçáo de um novo.

O Mestrado Profissional nos pareceu um caminho interessante. Primeiramente, por considerarmos as circunstâncias institucionais e históricas específicas da área de terapia ocupacional na FMUSP e na Universidade de São Paulo. Mas também porque é uma modalidade de Pós-Graduação Stricto Sensu focada na qualificação de pessoas que estejam engajadas em práticas profissionais e que desejam estudá-las e qualificá-las. O mestrado profissional tem essa característica marcante, como define a CAPES (BRASIL, 2019): um dos seus principais objetivos é capacitar profissionais para práticas avançadas, inovadoras e transformadoras dos processos de trabalho. Nesse sentido, privilegia pesquisas que se voltem para os problemas reais encontrados na esfera da atuação profissional.

Nosso programa pretende capacitar terapeutas ocupacionais para uma prática crítica e inventiva em açôes e serviços ligados a políticas públicas inclusivas, nas quais a comunidade tem lugar relevante. É composto por uma área de concentração - Terapia ocupacional, contextos comunitários e inclusão social - que abrigará estudos sobre a avaliação, o desenvolvimento e a qualificação teórico-prática de intervenções claramente voltadas a ampliar as oportunidades de participação e inclusão social de pessoas acompanhadas em terapia ocupacional.

O programa tem duas linhas de pesquisa. Uma, denominada "O brincar, a escola, a cultura e a participaçáo infantojuvenil”, constituída pelo estudo e desenvolvimento de práticas e recursos que apoiem a inclusão social de crianças e jovens, considerando o universo de atividades, relações sociais e contextos de sua vida cotidiana, que envolvem o brincar, a vida escolar e as várias atividades desenvolvidas no âmbito da família, da comunidade e de seus diferentes grupos sociais de pertencimento. A outra linha, "Participação social, trabalho, convivência e cuidado", foca os estudos e as estratégias profissionais que visam promover, junto a adultos e idosos, a independência e autonomia no autocuidado, no habitar, na vida familiar e comunitária, no trabalho e no acesso à produção de bens e valores sociais, bem como a 
produção e fortalecimento de linguagens e expressóes culturais e artísticas e o enfrentamento de situaçóes de negligência, violência e estigma.

Nas duas linhas, os estudos devem se fundamentar em noçóes de autonomia e vida cotidiana que alicerçam práticas contemporâneas de terapia ocupacional, associadas às perspectivas que reconhecem a riqueza da diversidade humana, valorizam a convivência com a diferença e o respeito aos direitos humanos. Esses temas também serão tratados em um conjunto de disciplinas obrigatórias e optativas, sendo parte dela conectada aos objetos de estudo que integram as linhas de pesquisa. Outras abordarão métodos e processos de pesquisa, em percursos reflexivos que visam contribuir com a ampliação e disseminação dos saberes da terapia ocupacional (MONZELI et al., 2018) e sua multiplicidade (GALHEIGO et al., 2018).

Por fim, o momento é de disposição para o enfrentamento crítico e criativo dos desafios colocados para a implantação de nosso programa de mestrado profissional, ainda no ano de 2019!

\section{Marta Carvalho de Almeida, Fátima Correa Oliver}

Mestrado Profissional em Terapia Ocupacional e Processos de Inclusão Social, Universidade de São Paulo - USP, São Paulo, SP, Brasil

\section{Referências}

BRASIL. Portaria n ${ }^{\circ}$ 60, de 20 de março de 2019. Dispóe sobre o mestrado e doutorado profissionais. Diário Oficial [da] República Federativa do Brasil, Poder Executivo, Brasília, DF, 22 mar. 2019.

EMMEL, M. L. G. Caminhos trilhados e contribuiçôes para o desenvolvimento da terapia ocupacional no Brasil. Cadernos Brasileiros de Terapia Ocupacional, São Carlos, v. 25, n. 1, p. 235-242, 2017.

GALHEIGO, S. M. et al. Produção de conhecimento, perspectivas e referências teórico-práticas na terapia ocupacional brasileira: marcos e tendências em uma linha do tempo. Cadernos Brasileiros de Terapia Ocupacional, São Carlos, v. 26, n. 4, p. 723-738, 2018.

GUEDES, S. C. C. A. R.; LOPES, R. E. O início da trajetória de institucionalização acadêmica da terapia ocupacional no Brasil: o que contam os(as) docentes pioneiros(as) sobre a criaçáo dos primeiros cursos. Cadernos Brasileiros de Terapia Ocupacional, São Carlos, v. 26, n. 2, p. 255-270, 2018.

LEMINSKI, P. Incenso fosse música. In: LEMINSKI, P. Distraídos venceremos. São Paulo: Brasilense, 1987.

MONZELI, G. A. et al. Perspectivas e tendências da Federação Mundial de Terapeutas Ocupacionais: um olhar sobre o Congresso Mundial 2018 - Cidade do Cabo, África do Sul. Cadernos Brasileiros de Terapia Ocupacional, São Carlos, v. 26, n. 3, p. 511-512, 2018. 